FACTA UNIVERSITATIS

Series: Visual Arts and Music Vol. 3, Nº 2, 2017, pp. 101 - 109

https://doi.org/10.22190/FUVAM1702101V

Original Scientific Paper

\title{
MUSIC PROGRAMS ON SERBIAN PUBLIC TV CHANNELS ${ }^{1}$
}

\author{
UDC 654.191:782/785 Radio-televizija Srbije
}

\section{Tatjana Vulić}

University of Niš, Faculty of Philosophy, Department of Communication Sciences and Journalism, Niš, Serbia

\begin{abstract}
During nearly half a century-long history, Radio and Television of Serbia, nowadays known as Serbia Public Broadcasting Service, met not only with diversity, but also with quality standards in terms of program requirements. Music programs of the Public Broadcasting Service is one of the possible indicators that show that high standards can be reached even in the time of "abundance" of the trash music that overwhelms the comercial television programs. The aim of this paper is to examine the quality and variety of the music programs of Belgrade Television (all three programs 1, 2 and RTS Digital), as well as the presence of various musical genres in these programs. The analysis was conducted on the basis of the RTS Centre for Research of Public Opinion, Programs and Auditorium, based on the 24-hour regular monitoring. The database was provided to us for the purpose of analysis in this paper. The aim of our research analys is the program type and the musical genre.
\end{abstract}

Key words: Radio and Television of Serbia, Serbia Public Broadcasting Service, music program, music genre, program standard

\section{INTRODUCTION}

The Greek philosopher Plato ${ }^{2}$ wrote about the importance of music for society and the state in almost all of his works, mainly in his Republic and in Laws. He interpreted the concept of music as based on the ethical principle, and pointed out that music strives to achieve the ethical ideal.

Received: September 2017 / Accepted November 2017

Corresponding author: Tatjana Vulić

University of Niš, Faculty of Philosophy, Department of Communication Sciences and Journalism E-mail: tatjana.vulic@ @ilfak.ni.ac.rs

${ }^{1}$ Belgrade constituent Television is a part of RTS, that is, Serbia Public Broadcasting Service. Belgrade television comprises of RTS 1, RTS 2, RTS Digital, as well as of RTS SAT and specialized channel "RTS channel package" which are out of scope for this paper.

${ }^{2}$ Plato was the Greek pholosopher and orator , the founder of the Athens Academy (427 BC-347 BC). 
Plato believed that the better the music in a state is, the state itself will be better, and advised the statesmen to seriously track the trends and changes of styles in music, because changes in style also announce the changes in basic laws. In his work Laws, Plato restricts and directs musical creation. He accepts some musical instruments which he finds useful for the people (lyre and cithara), while he rejects flute, trigonon and pektida, as he thought they could negatively affect the people. The purpose of music should be to promote harmony, balance and order. Plato believes that music promotes the moral law and that it gives soul and spirit to the universe. Music develops the mind and imagination and it should be an example of the harmony for the cities and the state. In his work Politics (1975), Plato's student, Aristotle ${ }^{3}$ emphasized that emotion is created by melody and rhythm, and that music has the power to shape human character.

We can experience and understand music as entertainment and enjoyment, as well as fun in times of leisure, a profession or an expression of a certain identity. Music can also be interpreted as a specific language of the media. The definition of communication by Radojković and Djordjević implies that it is a "process of exchange of signs and symbols" $(2001,22)$ which leads us to think that we can regard music as a good basis for the development of both media literacy and culture of the audience. Nowadays, media have the power to address and reach out to a huge number of citizens, and at the same time influence and create public opinion. The age which we live in can easily be called the culture of information or the culture of mass communication media where the emphasis is on television as a powerful medium that affects all our senses, creating the illusion of being there and everywhere, anywhere in the world at the same time. Hence, we can also talk about the social responsibility of the media (television) in creating cultural patterns, cultural values for the audience as well as its educational role. Rus-Mol and Zagorac Kešer talk about: "Media and journalism are an integral part of the entertainment society and the entertainment economy. They form and permeate the society" $(2005,18)$. Aracki $(2012)$ also draws attention to this dimension of television, emphasizing that the opportunity for the successful work of the television particularly depends on the good knowledge of the leisure time structure of the audience, which, according to numerous studies, devotes considerable attention to the music programs. "In order to achieve the maximum effectiveness of this industry, and to preserve the authenticity of the mass auditorium, it is necessary to integrate the previously divided segments: mass media and entertainment" (Aracki 2012,173).

If we chose to forget about the basic cultural values we could find ourselves facing the following peril: "By adapting to valid social norms, cultural patterns and cultural industry, without the ability to influence the creation of authentic human needs, the individual is forced to lower the taste and give up on his/her own choice. Relying on the broadest layers of less-educated audiences, the overall commercialization causes a lot of products on the market that are good to be mass produced" (Božović 1984, 35). The music program is characterized by powerful communication capabilities, while its program functions and its very effects are linked to historical and social environment and to culture and art.

Television can definitely be regarded as one of the greatest, if not the greatest achievement of the $20^{\text {th }}$ century. From the moment television appeared, as McLuhan says, "no one has been satisfied with the mere knowledge of French or English poetry" (2008, 293). It was created as

\footnotetext{
${ }^{3}$ Aristotle (384 BC- 322BC) was a Greek philosopher and one of the most influental individuals of the classical eriod. He was the teacher of Alexander the Great.
} 
the entertainment medium ${ }^{4}$, but with the dominant share of the news program and clearly defined functions - informative, educational and entertaining. "According to some critics, television is the most perfect invention to waste time" says (Đukić 2007, 200). For other authors, television is "the medium that replaced the theatre, town square, the cafe and the circus, but inevitably incorporated in it at least one part of each of these" (Todorović 2009, 291).

Since the very beginning of television, an indispensable part of the program concept was the music program. A very important program part of the Public Broadcasting Service of Belgrade Television is the music program with its music shows based on the type of music and the audience. The music program is broadcast at different times and it includes concerts of different length and five-minute music sections, intended for all ages. Radio Television of Serbia 1 (RTS1) music shows include two folk music shows - Music with no borders and Fly, fly my dear song (Serbian: Pesma bez granica and Leti, leti pesmo moja mila), as well as one show that promotes contemporary pop and rock scene and young bands in Serbia and the region - Jelen top 10. RTS2 adapts the music program to all various target groups; it is broadcast at different times of the day and conceptually covers current events and manifestations in the music world, as well as archived recordings of concerts and other music events. In addition to the so-called turbo-folk music, Radio Television of Serbia also provides almost all music genres. However, the musicians and editors of the RTS music program put special emphasis on evergreen, pop, classical and folk music, while rock music is slightly less present. In addition to many concerts, this program also includes various shows, for example, documentaries, live performances in the studio, etc.

\section{Music Program on Serbian Public Broadcasting Service}

The initial principles of public broadcasting services were set up by the first BBC (British Broadcasting Corporation) director, John Reith, in the very charter of the corporation. Soon after, the British Parliament defined the public broadcasters as the "service to broadcast programs for information, education and entertainment purposes" (Martin and Viringa 2000, 50). In his book "Public Broadcasting Service Serving the Citizens", Rade Veljanovski defines the public broadcasters as follows: "Public broadcasting service is a non-profit, independent radio and television organization, founded on behalf of general public and financed from public revenues, which meets the needs of the largest possible number of citizens, that is, the widest public, impartially and without discrimination with diverse, balanced, and high-quality programs" $(2005,28)$. The principles which the public broadcaster is based on are also listed in the collection of documents and texts "Public Service Broadcasting in Transition" (Prajs \& Reboj, 2002). In addition to the principle of universality, diversity and independence, a new principle is mentioned - recognition. The principle of recognition refers to program quality and access to topics and it is extremely important in the media environment itself, where the public broadcasting service works together with commercial media.

\footnotetext{
${ }^{4}$ When in 1936 regular broadcast began from Alexandra Palace, the BBC decided that in addition to the news, the popular song Magic Rays of Light would be broadcast as well.
} 
The Broadcasting Act $^{5}$ was passed in 2002 in order to define and regulate the Serbian Public Broadcasting Service with the legal provisions. Article 4 defines the following: "Public Broadcasting Service: production, purchase, processing and broadcasting of informative, educational, cultural and artistic, children, entertainment, sports and other radio and television programs of general interest to citizens, particularly for the purpose of exercising their human and civil rights, the exchange of ideas and opinions, the cultivation of political, gender, inter-ethnic and religious tolerance, as well as the preservation of national identity.",

By aligning the program content with the standards prescribed and expected from the Public Broadcaster of Radio and Television of Serbia, they they are supposed to provide a diverse and quality program, created according to professional standards, which largely meets the needs and expectations of the citizens. Based on the data by the RTS Centre for Research of Public Opinion, Programs and Auditorium ${ }^{7}$, RTS was the most watched television for 342 days last year. Moreover, according to the data by this Centre, almost three and a half million citizens of Serbia daily watch RTS 1 programs. Some of the most watched broadcasts and programs on RTS 1 are sports events, domestic series ${ }^{8}$, news program at 19:30 and the quiz called Slagalica. The most watched broadcasts and TV shows on RTS 2 are sports events, broadcasts of Serbian Parliament sessions, domestic movies, foreign series, Trezor, cartoon Johnny Test, Junior Eurovision Song Contest, The Vienna New Year's Concert, etc.

In $2016^{9}$, both RTS1 and RTS 2 had an increase in ratings ${ }^{10}$ compared to 2015 and compared to all other national television stations. Other researchers and Public Opinion Research Centres have also reported similar data and results concerning their surveys on television programs ratings. ${ }^{11}$ Furthermore, surveys related to music programs are rare and not very current. Information on the ratings of such programs is present only as part of some analysis of the overall public broadcasting service program and of commercial televisions.

However, we cannot disregard the fact that music is: "An essential and obligatory element of everyday program", and that "television strongly stimulated musical creativity, launched industrial (commercial) production of all music genres, especially the entertaining ones, and enabled music to become an enriching factor of human existence" (Ilić 2006, 154). As part of the music program of the Serbian Public Broadcaster, various music genres, as well as music shows are produced and broadcast, "which originate as the original

\footnotetext{
${ }^{5}$ http://nuns.rs/codex/law/98/zakon-o-radiodifuziji.html, visited on 6/8/2017.

${ }^{6} \mathrm{http}: / /$ nuns.rs/codex/law/98/zakon-o-radiodifuziji.html, visited on 6/8/2017.

http://www.rts.rs/page/rts/sr/CIPA/story/171/istrazivanja/2600642/gledanost-tv-programa-s-nacionalnompokrivenoscu-u-2016.html, visited on 6/8/2017.

${ }^{8}$ Premiers of domestic TV series Selo gori, a baba se češlja, Ubice mog oca, Gorčilo, as well as the reruns of the TV shows Čizmaši, Komšije, Montevideo bog te video and Ranjeni orao.

http://www.rts.rs/page/rts/sr/CIPA/story/171/istrazivanja/2600642/gledanost-tv-programa-s-nacionalnompokrivenoscu-u-2016.html, visited on 6/8/2017.

${ }^{10}$ According to the data provided by this Center, an average viewer of the RTS 1 has over 60 years, finished highschool and is mainlyfrom Central Serbia and from the urban áreas.

${ }_{11}$ See: http://www.rem.rs/uploads/files/PDF/6529-Analiza\%20medijskog\%20trzista\%20u\%20Srbiji\%20\%20final.pdf , visited on 6/8/2017. http://www.novinarska-skola.org.rs/sr/wp-content/uploads/2015/10/Izvestajo-monitoringu-programskih-sema-Radio-televizije-Vojvodine-i-Radio-televizije-Srbije-oktobar-2015.pdf,

visited on 6/8/2017. http://www.novinarska-skola.org.rs/sr/wp-content/uploads/2016/12/NNS_publikacija_ final.pdf, visited on 6/8/2017. http://www.novinarska-skola.org.rs/sr/wp-content/uploads/2016/10/FR4.pdf, visited on 6/8/2017.
} 
product of imagination and author's inspiration, as the initiative and the undertaking of the Belgrade Television music program editors (Ilić 2006, 154). Unlike some other commercial stations, apart from far greater genre diversity, Radio Television of Serbia preserves the uniqueness of music genres and resists the eruption of turbo folk music and its new genres and types. Thus, for example, folk music is based on folk music tradition, while it also played a significant role in promotion and development of rock'n'roll culture, as well as in the popularization of jazz and both classical and contemporary composers' music. Moreover, the creation and broadcasting of classical music is extremely important for the expansion of music culture and the increase of the quality level of the television program.

\section{RESEARCH}

Aims:

1. Investigate which RTS channel broadcasts the fewest and which one the most music programs.

2. Investigate whether music genre diversity is present on the Radio Television of Serbia in music programs.

3. Investigate what is the most present genre in music programs, and what is the least present one.

Sample:

The analysis was conducted on the basis of the RTS Centre for Research of Public Opinion, Programs and Auditorium, based on the 24-hour regular monitoring. The database was given to us for the purpose of the analysis in this paper and it includes the monitoring of music programs on all three RTS channels between January 1st and April $10^{\text {th }}, 2017$ which makes a total of 100 days of programs broadcastsby the Serbia Public Broadcaster.

\subsection{Results and Discussion}

Review 1: Percentage of musical programs broadcast on three RTS channels between January $1^{\text {st }}$ and April $10^{\text {th }}, 2017$ (100 days)

\begin{tabular}{lr}
\hline Channel & Result \\
\hline RTS 1 & $0.5 \%$ \\
RTS 2 & $8.8 \%$ \\
RTS 3 & $33.4 \%$ \\
\hline
\end{tabular}

Review 1 contains the results of the presence of music programs on all three RTS channels between January $1^{\text {st }}$ and April $10^{\text {th }}$, 2017 which clearly show that music programs are least present on RTS 1 with only $0.5 \%$ of all programs, and most present on RTS 3 with $33.4 \%$ of all programs. This ratio of music programs corresponds to the program and the editorial policy of this Public Broadcaster programs. Therefore RTS1 provides information and news, RTS 2 deals with educational topics, while RTS 3 is intended for educational and entertainment topics. The above results of this review confirmed our first, initial hypothesis that music program is the most present on RTS 3, and the least present on RTS 1. 
Review 2: Music genres on RTS 1

\begin{tabular}{lr}
\hline Genre & Percent \\
\hline Folk music & $0.1 \%$ \\
Pop music & $0.4 \%$ \\
Mixed misic shows & $0.0 \%$ \\
\hline
\end{tabular}

RTS 1 is organized and perceived as a program primarily intended to inform the citizens, which is why there is a very low presence of the music program on this channel, that is, only $0.5 \%$ of the total broadcastprograms. The Review - Music genres on RTS 1 (Table 2) clearly identifies the types of music genres present on this channel - folk music only $0.1 \%$ and popmusic $0.4 \%$. Between January and April of 2017, the period when the monitoring took place, there were no mixed music shows on RTS1.

Review 3: Music genres on RTS 2

\begin{tabular}{lc}
\hline Genre & Percent \\
\hline Folk music & $0.1 \%$ \\
Pop music & $0.4 \%$ \\
Mixed music shows & $0.0 \%$ \\
Jazz & $0.6 \%$ \\
Classical music & $2.8 \%$ \\
\hline
\end{tabular}

Unlike RTS 1, the RTS 2 channel has much broader music genre diversity. During the observed period, the most frequent ones were the mixed music shows with $3.3 \%$ of the overall program, followed byclassical music with $2.8 \%$, while folk and pop music had the same percentage ratio of $1.1 \%$, while jazz was present in $0.6 \%$ of the total program. So, the total percentage ofmusic programs on RTS 2 channel was $8.8 \%$ during the observed period.

Review 4: Music genres on RTS 3

\begin{tabular}{lr}
\hline Genre & Percent \\
\hline Folk music & $2.8 \%$ \\
Pop music & $4.7 \%$ \\
Mixed music shows & $4.8 \%$ \\
Jazz & $4.9 \%$ \\
Classical music & $16.2 \%$ \\
\hline
\end{tabular}

Regarding the program concept, it was expected that RTS 3 would have the highest percentage, that is, $33.4 \%$ compared to the total broadcastprogram. On this channel, as shown in Table 4, classical music is the most present with $16.2 \%$, while folk music is the least present with $2.8 \%$. Other genres are present with similar percentage on this channel, that is, pop music takes up $4.7 \%$ of overall music program. Mixed music shows take up $4.8 \%$ and jazz $4.9 \%$ of overall music program. 
Review 5: Percentage of all music genres on all three RTS channels between January and April, 2017

\begin{tabular}{lrrrr}
\hline Genre & RTS 1 & RTS 2 & RTS3 & Total \\
\hline Folk music & $0.1 \%$ & $1.1 \%$ & $2.8 \%$ & $4 \%$ \\
Pop music & $0.4 \%$ & $1.1 \%$ & $4.7 \%$ & $6.2 \%$ \\
Mixed music shows & $0.0 \%$ & $3.3 \%$ & $4.8 \%$ & $8.1 \%$ \\
Jazz & $0.0 \%$ & $0.6 \%$ & $4.9 \%$ & $5.5 \%$ \\
Classical music & $0.0 \%$ & $2.8 \%$ & $16.2 \%$ & $19.0 \%$ \\
\hline
\end{tabular}

Review 5 shows the percentages that all music genres take up on all three RTS channels. Although classical music is not present at all on RTS 1, it was still the most present one during this time period with $19 \%$. The other music genres were represented with a much lower percentage: mixed music shows took up $8.1 \%$, pop music $6.2 \%$, jazz $5.5 \%$. Although present on all three RTS channels, folk music is still the least present with only $4 \%$.

\section{CONCLUSION}

Providing media services and meeting the communication needs of all citizens using multiple and various programs and contents is one of the basic functions of the public broadcaster. Moreover, independence and autonomy are closely linked to this. Implementation of these elements is a guarantee that the public requirements will be met. "Studies on the genre diversity on TV channels are seen as, if not the main one, then at least as a necessary ancillary element in assessing the quality of the functioning of the media and the success of media policy" (Matic 2009, 25). The idea of media diversity is noticed, as Vitković (2010) points out, through the obligation of the media to provide socially acceptable programs that reflect social, political and cultural diversity, and not only to meet the demands of the majority of the audience: "In order to achieve media diversity, the media must encourage innovative content even if it is not popular because it encourages free thinking (the critical role of the media) and citizens' participation through the multitude of different information (the expressive role of the media in meeting the demands of citizens)" (Vitković 2010, 144). At the same time, Vitković emphasizes that pluralism and diversity cannot be understood as synonyms, since diversity as a multitude is sometimes dangerous, while pluralism implies engagement in that multitude.

The RTS music program could be one of the indicators of the transformation of RTS into the Public Broadcasting Service and its meeting of public service standards, including diversity and high quality. Nowadays, the music program of RTS is a product of complex influences, which comprise, among other things, those belonging to Serbian media environment that is increasingly subjected to commercialization. Along with the new and popular genres, it is deeply-rooted that it creates the feeling of spiritual pseudoneeds of citizens "behind which stands an overt tendency to create an idolization of the singers which brings profit to the producers of the phonographic industry" (Ilic 2006, 157). Television is indeed a powerful media through which the education and popularization of program content is efficiently implemented, but it is also a powerful driver in the cultural life of citizens. "Television editors who run music editorials are offered the opportunities to influence the creation of criteria, to improve the values of the 
environment which they live in. Namely, music is ... the best type of cultural activity. Music, meaning the real folk, pop, classical, and any other genre, music of rich motifs and gorgeous harmony, should be defended against deliberate and involuntary attacks of kitsch" (Ilić 2006, 163). If Belgrade TV had not showen The Vienna New Year's Concert for many years now, thus contributing to its popularization, this classical music show would not, as we have already mentioned, be one of the most watched music shows in 2016 on RTS 2 channel. Snežana Nikolajević"12 believes that "The abundance of different types of music programs on television also contributes to the expansion of music and of television" (based on Ilić 2006, 159). Television contributes to the popularization of music. Public Broadcaster TV channels 1, 2 and 3 broadcast different music genres with programs that contribute to the popularization of different music genres and the promotion and development of certain music genres and the expansion of music culture. The aim of this paper was to emphasize the quality and diversity of the music program of Belgrade Television (considering all three channels - 1,2 and 3 (RTS Digital), as well as to show the presence of various music genres on these channels.

The results of the 100 day-long monitoring, that is, from January 1st to April $10^{\text {th }}$, 2017, show that all three RTS channels show that the Serbia Public Broadcaster provides diverse music genres and, according to the diversity of program content and structure, these channels to a large extent meet the requirements which arise from the general concept of the Public Broadcasting Service, as well as from the Law on Public Broadcasting Services of the Republic of Serbia. The music program is the least present on RTS 1, which we had assumed due to the program concept of this channel. RTS 2 broadcasts more music programs, but there is a balance with other programs that are broadcast on this channel, for example, scientific and educational programs, documentaries, cultural programs, featured programs. The greatest presence of music programs is on RTS 3 which was designed with the intention to broadcast this kind of program. The greatest presence of classical music as well as the significant presence of mixed music shows, pop and jazz music testify about the contribution of the Public Broadcaster to the overall cultural life of citizens. Despite the abundance of new music styles that mimic the oriental sounds and the wave of kitsch, which is broadcast largely on commercial national television channels, there are also other music types and other genres that are broadcast on Radio and Television of Serbia. This can be considered a good "defence" from the shift in the musical taste of Serbian citizens towards cheap and trash music genres and types. Serbian public broadcaster's music program is one of the possible indicators that show that high standards can be reached.

Acknowledgement: This paper is a part of the project number 179008 financed by the Ministry of Education and Science of the Republic of Serbia.

\footnotetext{
${ }^{12}$ Prof. Snežana Nikolajević, PhD musicologist, pianist, music critic, longtime editor of Belgrade Television music program.
} 


\section{REFERENCES}

Aracki, Z. (2012). Srpsko novinarstvo i mas mediji u postindustrijskom društvu, in: Lj. Milosavljević, B. Stevanović, G. Stojić (Eds.), Tradicija, modernizacija, identiteti 2. Niš, Filozofski fakultet, Centar za sociološka istraživanja:169-181.

Aristotel. (1975). Politika. Beograd: BIGZ.

Božović, R. (1984). Lavirinti culture. Beograd: Radnička štampa.

Đukić, A. (2007). Televizija. Beograd: Čigoja štampa.

Ilić, M. (2006). Rađanje televizijske profesije. Beograd: Clio.

Makluan, M. (2008). Razumevanje medija. Zagreb: Golden Marketing, Tehnička knjiga.

Matić, J. (2009). Raznovrsnost TV programa u Srbiji, in: D. Valić Nedeljković (Ed.), Medijski skener. Novi Sad, Novosadska novinaska škola: 24-70.

Platon. (2002). Država. Beograd: BIGZ.

Platon. (1990) Zakoni - Epinomis. Beograd: BIGZ.

Prajs, M., M. Reboj (2002). Radio-difuzija javnog sevisa u tranziciji. Beograd: B92.

Radojković, M.,T. Đorđević (2001). Osnove komunikologije. Beograd: FPN, Čigoja.

Rus-Mol, Š. (2005). Novinarstvo. Beograd: Clio.

Veljanovski, R. (2005). Javni RTV servis u službi građana. Beograd: Clio.

Vitković, B. (2010). Konceptualna razgraničenja: pluralizam i diverzitet, CM - Časopis za usmeravanje komunikacija (15), Beograd, Novi Sad, FPN, Institut za usmeravanje komunikacija: 143-162.

Šingler, M., S. Viringa (2000). Radio. Beograd: Clio.

Internet sources

http://nuns.rs/codex/law/98/zakon-o-radiodifuziji.html, visited on 6/8/2017.

http://www.rts.rs/page/rts/sr/CIPA/story/171/istrazivanja/2600642/gledanost-tv-programa-s-nacionalnompokrivenoscu-u-2016.html, visited on 6/8/2017.

http://www.rem.rs/uploads/files/PDF/6529-Analiza\%20medijskog\%20trzista\%20u\%20Srbiji\%20-\%20final.pdf visited on 6/8/2017.

http://www.novinarska-skola.org.rs/sr/wp-content/uploads/2015/10/Izvestaj-o-monitoringu-programskih-sema-Radiotelevizije-Vojvodine-i-Radio-televizije-Srbije-oktobar-2015.pdf, visited on 6/8/2017.

http://www.novinarska-skola.org.rs/sr/wp-content/uploads/2016/12/NNS_publikacija_final.pdf, visited on 6/8/2017.

http://www.novinarska-skola.org.rs/sr/wp-content/uploads/2016/10/FR4.pdf, visited on 6/8/2017.

\section{UČEŠĆE MUZIĆKOG PROGRAMA NA JAVNOM MEDIJSKOM SERVISU SRBIJE}

U istoriji dugoj gotovo pola veka Radio-televizija Srbije, danas Javni medijski servis kao programske zahteve postavljala je ne samo raznovrsnost već i kvalitet programa. Muzički program Javnog medijskog servisa $^{13}$ jedan je od mogućih indikatora koji pokazuje da je visoke standarde moguće dostići čak $i$ vremenu "obilja" muzičkog treša kojim su preplavljeni programi komercijalnih televizija. Cilj rada je da ispitamo kvalitet i raznovrsnost muzičkog programa Televizije Beograd (posmatrajući sva tri programa odnosno Prvi, Drugi i RTS Digital), kao i zastupljenost različitih muzičkih žanrova na ovim programima. Analiza je sprovedena na osnovu baze podataka Centra RTS-a za istraživanje javnog mnjenja, programa $i$ auditorijuma $i$ to 24-časovnog redovnog monitoringa. Baza podataka nam je ustupljena za potrebe analize u ovom radu. Jedinica analize u istraživanju je vrsta programa i muzički žanr.

Ključne reči: Radio-televizija Srbije, Javni medijska servis Srbije, muzički program, muzički žanr, programski standard

\footnotetext{
${ }^{13}$ Televizija Beograd deo je RTS-a, odnosno Javnog medijskog servisa Srbije. Televiziju Beograd čine Prvi i Drugi program, RTS Digital kao i RTS SAT i specijalizovani kanali "Paket kanal RTS" koji nisu predmet ovog rada.
} 